\title{
Dünyada ve Ülkemizde Online Uyuşmazlık Çözümleri Bağlamında Online Tahkim ve Uygulamaları
}

\author{
Seda 0̈zmumcu* $\odot$
}

Öz

Bu makale, dünyada 1990'lı yıllardan itibaren internetin icadı ile başlayan ve yakın zamanlarda giderek daha da etkin hale gelen online uyuşmazlık çözümleri bağlamında online tahkim ile ilgilidir. Günümüzde büyük bir hızla gelişen teknoloji, beraberinde uyuşmazlık çözümlerine farklı ve yeni bir bakış açısı getirmektedir. Bu yeni yaklaşım, uyuşmazlıkların çözümünün klasik yöntemlerle yüz yüze duruşma veya oturumlar şeklinde yapılması gibi geleneksel anlayışı değiştirerek, gerçek dünyayı internet üzerinden siber ortama taşımayı öngörmektedir. Dünyada tahkim ve arabuluculuk gibi alternatif uyuşmazlık çözümleri, çeşitli ülkelerde kurumsal olarak muhtelif kuruluşlar tarafindan gerçekleştirilmektedir. Bu kuruluşların bir bölümü, 2010 yılından itibaren uygulamalarını online uyuşmazlık çözümleri kapsamında da genişletmiş bulunmaktadır. Özellikle 2015 yılından itibaren bazı ülkelerdeki tahkim kurumlarının, online uyuşmazlık çözümleri bağlamında offline tahkimi, internet üzerinden siber ortamda gerçekleştirmek amacıyla, kendi bünyelerinde online tahkim kurallarını düzenledikleri görülmektedir. Çalışmamızda bu konu ile ilgili dünyadaki çeşitli kurumların online tahkim uygulamalarından örneklere yer verilmektedir. Ülkemizde ise, 6570 sayılı İstanbul Tahkim Merkezi Kanunu ile uyuşmazlıkların alternatif yollarla çözümü amacıyla kurulan İstanbul Tahkim Merkezi, bu alanda hizmet veren ilk ve aynı zamanda genç bir kurumdur. Günümüz teknolojilerinin uyuşmazlık çözümü üzerine getirdiği bu önemli etkiler, COVID-19 salgını ile bambaşka bir görünüm kazanmıştır. Adalete erişim ve hak arama özgürlüğü belirli ölçülerde online ortama taşınmaya başlamıştır. Bu bağlamda İstanbul Tahkim Merkezi'de internet ortamında online yapılacak duruşmalara ait kural ve esaslarını yakın bir zamanda yayınlamıştır. Online uyuşmazlık çözümleri kapsamında, online tahkim açısından hızıılık, etkililik ve az masrafla uyuşmazlıkların çözümü, bu sürecin olumlu yönlerini meydana getirmekle birlikte, online ortamda gerçekleştirilen tahkim yargılamasının bazı olumsuz yönleri de bulunmaktadır. Hiç şüphesiz internete erişim bakımından ortaya çıkabilecek teknoloji tabanlı teknik sorunlar; COVID-19 salgını ile daha da hızlanan teknolojik gelişmeler aracılığı ile süratle çözümlenebilecektir. Fakat asıl sorun, internete erişimden daha da öte adalete erişim noktasında adil yargılanma, hukuki dinlenilme hakkı gibi yargılamanın temel ilkelerinin online tahkim ortamında da gerçekleştirilmesini sağlamak, adil ve adaletli kararlar verilmesini yerine getirmektir. Makalemiz, COVID-19 ile birlikte bu konular üzerinde yeniden düşünmeyi hedeflemektedir.

\section{Anahtar Kelimeler \\ Online uyuşmazlık çözümü , Online tahkim, Hakem, Siber ortam, COVID 19, Adalete erişim, Adil yargılanma hakkı}

Online Arbitration and its Applications in the Context of Online Dispute Resolutions in the World and Our Country

\begin{abstract}
This article examines online arbitration within the context of online dispute resolution, which began with the advent of the internet during the 1990s and has become efficient over time. Contemporarily, fast-evolving technology has engendered a new perspective to dispute resolution. This new approach has altered the traditional understanding of dispute
\end{abstract}

* Sorumlu Yazar: Seda Özmumcu (Prof. Dr.), İstanbul Üniversitesi, Hukuk Fakültesi, Özel Hukuk Bölümü, İstanbul, Türkiye. E-posta: ozmumcu@istanbul.edu.tr ORCID: 0000-0002-6395-8668

Atrf: Ozmumcu S, “Dünyada ve Ülkemizde Online Uyuşmazlık Çözümleri Bağlamında Online Tahkim ve Uygulamaları” (2020) 78(2) İstanbul Hukuk Mecmuası 431. https://doi.org/10.26650/mecmua.2020.78.2.0007 
resolution from classical methods such as face-to-face hearings or sessions to using the internet, while causing a shift from the real world to the cyberspace. Alternative dispute resolution methods such as arbitration and mediation are conducted by various institutions across countries around the world. Some of these institutions expanded their application to include the scope of online dispute resolution after 2010. More specifically, arbitration institutions in some countries introduced regulations regarding online arbitration in 2015. They did so with the aim of having online arbitration within the scope of online dispute resolution in cyberspace using the Internet. This study shares examples from online arbitration applications of various institutions around the world. The Istanbul Arbitration Center was founded under the Law on Istanbul Arbitration Center numbered 6570 , with the aim of resolution of disputes by alternative methods in Turkey. This is a nascent and the first institution to provide such service in Istanbul. These significant measures engendered by recent technologies on dispute resolution have gained a completely different importance with the coronavirus disease 2019 (COVID-19) pandemic. Access to justice and the right to legal remedies have moved to online platforms at specific rates. Within this scope, the Istanbul Arbitration Center has recently published the Procedures and Principles for Online Hearings. Speed, efficiency, and resolution of disputes with lower costs constitute the positive aspects of online arbitration, which are also characterized by few negative aspects. Undoubtedly, technical problems relating to internet access, which are more technology-based, can be resolved faster due to constant developments in the technological field during the COVID-19 pandemic. However, the actual problem relates to ensuring fair and righteous decisions while enabling justice and the right to a fair trial in an online arbitration area. This article aims to reconsider those issues along with the challenges engendered by the COVID-19 pandemic.

\section{Keywords}

Online dispute resolution, Online arbitration, Arbitrator, Cyberspace, COVID-19 access to justice, Right to fair trial

\section{Extended Summary}

Online dispute resolution has evolved over the years, especially rapidly after the 1990s, with the advent of the internet. Among the dispute resolution methods facilitated in the cyberspace using the internet, online arbitration procedures can also be included. Online arbitration is used by various institutions that resolve disputes through institutional arbitration and mediation methods in many countries around the world, such as the USA, UK, Canada, China, Japan, Australia, and Russia.

This is done especially for international commercial arbitration since parties to the dispute are located in different and distant geographical areas. Thus, the use of online arbitration within the scope of online dispute resolution is becoming mandatory. Parties are gravitating to this type of arbitration relative to state courts due to positive aspects such as saving time, low costs, and confidentiality in terms of safeguarding the business life.

With the coronavirus disease 2019 (COVID-19) pandemic, this process has started to move beyond the traditional methods of arbitration. This situation has also engendered institutions that perform arbitration and mediation to start initiatives to develop online arbitration procedures. This study aims to provide examples from across the world, in general, and Turkey, in particular, from the institutions that have started to provide alternative dispute resolution methods in the form of online 
platforms. In this context, online arbitration serves as an important choice to the parties of a dispute in terms of "access to justice" in a world struggling with the COVID-19 pandemic.

Along with its positive aspects, the method carries some negative features. Thus, while preparing this study, we have observed some concerns regarding online dispute resolution using the internet in academic publications that we analyzed. Those concerns are not merely limited to technical malfunctions happening in electronic platforms. In the $21^{\text {st }}$ century, where there is fast developing technology, progress in resolving technology-based problems may be achieved more quickly.

However, the problem is not solely related to this issue. Online dispute resolution includes not only easier access to justice but also the rendering of fair and righteous decisions. Basic principles of judgment such as the right to a fair trial and the right to be heard are much more important in resolving disputes through online arbitration. Online arbitration differentiates from online mediation in specific characteristics. In mediation, the mediator who is authorized to resolve the dispute among the parties is only authorized to resolve the specific conflict. Therefore, since mediation cannot be considered a judicial activity, the mediator does not effectively render a decision. The function of the mediator extends only insofar as to resolve the conflict that underlies the actual dispute of parties. For sure, there are ethical principles that the mediator must abide by. However, the mediator is not conducting a judicial activity.

In contrast, arbitration can be executed as binding or non-binding arbitration around the world. Arbitration is binding and an arbitrator or an arbitral tribunal renders an award as a result of adjudication. Thus, an award rendered in arbitration should be binding similar to how a decision rendered by state courts are also binding. Moreover, if the conditions are met, then the parties can apply for legal remedies in order to annul the award. At this very point, abiding by the basic principles such as the right to a fair trial and the right to be heard is becoming more important in this virtual reality.

Online arbitration within the scope of online dispute resolution should be seen as a natural extension to the fast-developing technology in this digital age. Our world is reshaping against the backdrop of the contemporary situation. Despite the fact that the resolution of disputes through online arbitration is gaining popularity owing to fast-developing technology, traditional methods will still continue to hold their place and may still be relatively efficient. As such, it should not be forgotten that justice should never be compromised against speed no matter the distance, low costs, and efficiency engendered by online arbitration within the scope of online dispute resolution. 


\section{Dünyada ve Ülkemizde Online Uyuşmazlık Çözümleri Bağlamında Online Tahkim ve Uygulamaları}

\section{Giriş}

Online tahkim (online arbitration), esas olarak online uyuşmazlık çözümleri (online dispute resolution) kapsamı içinde yer alan alternatif uyuşmazlık çözüm yöntemlerinin internet ortamında online veya çevrimiçi olarak yapılması için öngörülmüş uyuşmazlık çözüm yöntemlerinden biridir. Dünya genelinde online uyuşmazlık çözüm yöntemlerinin 1990'l yıllardan itibaren ivme kazandığı ve hızla gelişen teknoloji ile birlikte başta ticari uyuşmazlıklar olmak üzere birçok hukuki alanda ve artan oranda yaygın hale geldiği gözlenmektedir.

Günümüzde küreselleşen ve büyük bir hızla dijitalleşmeye doğru geçen dünya toplumları, COVID-19 ile birlikte bir taraftan, bu yeni dünya düzenine kendilerini adapte edip uyarlamaya çalışırken, diğer taraftan da bu salgın ile birlikte şimdi veya ileride mevcut olabilecek uyuşmazlıklarını en uygun hangi yöntemlerle çözüme kavuşturacaklarının yollarını aramaya başlamıştır. Bu konuya hukuk sistemimiz açısından bakıldığında, uyuşmazlıkların yargı yolları dışında ve fakat yargının tamamlayıcısı niteliğinde olan alternatif uyuşmazlık çözüm yöntemleri ile çözümünün yeni ve gelişmekte olan bir alan olduğunu söylememiz gerekir. Ancak Türk hukuk sisteminde de geleneksel veya offline tahkime ilişkin kural ve esasların, COVID-19 ile birlikte online tahkime dönüşümü yönünden, yeni bir görünüm kazandığı görülmektedir.

Yaşadığımız çağda devlet mahkemeleri önünde görülen davaların yargılama hızının, artarak ticari hayatın ihtiyaçlarını karşılayamaz hale geldiği görülmektedir. ${ }^{1}$ $\mathrm{Bu}$ sebeple tarafları, tahkime ve hakem yargılamasına yönelten nedenlerin başında, yargılama sürecinin hızlığ tasarrufunun yanı sıra sürecin gizliliği gibi unsurlar gelmektedir. ${ }^{2}$

Bu konuya Türk hukuk sistemi yönünden bakıldığında, medeni yargılama hukukunda tahkime ilişkin yasal düzenlemeler, 01.10.2011 tarihinde yürürlüğe giren 6100 sayılı Hukuk Muhakemeleri Kanunu ile yeniden revize edilmiştir. Bu bağlamda yine alternatif uyuşmazlık çözüm yöntemlerinden biri olan arabuluculuk, 6325 sayılı Hukuk Uyuşmazlıklarında Arabuluculuk Kanunu ile 22.06.2013 tarihinde yürürlüğe girdiğinden bu noktada yeni bir kanun olarak görülmelidir. Fikrimizce, tahkim gibi önceden var olan ve fakat yeni düzenlemelerle fonksiyonu güncelleştirilip, etkinliği artırılan ve arabuluculuk gibi bağımsız bir yasal düzenlemeye kavuşan bu uyuşmazlık

Görkem Çakır/Erdinç Dalar, “Arbitration via Internet Environment Online Arbitration”, (2018), 19, GSI Articletter, 224.

Ergun Özsunay, "Tahkim Yargılamasında Mahremiyet”, (2004), 2, İBD, 541; Yavuz Alangoya, Medeni Usul Hukukumuzda Tahkimin Niteliği ve Denetlenmesi, (Fakülteler Matbaası 1973), 4; Nevhis Deren-Yıldırım, "Tahkimin Olumlu ve Olumsuz Yönleri”, (2002), 4, ABD, 38 vd; H.Yavuz Alangoya/M. Kâmil Yıldırım/Nevhis Deren-Yıldırım, Medeni Usul Hukuku Esaslarl, (7.Baskı, Beta 2009), 595; Çakır/Dalar, (n 1), 224. 
çözüm yöntemleri, hukuk sistemimiz içinde yerini ve etkinliğini belli bir hıla sağlamaya çalışırken, beklenmedik bir şekilde karşı karşıya kaldığımız COVID-19 salgını, Batı hukuklarında temelleri yıllarca önce atılmaya başlamış ve belli aşamalara gelmiş olan online uyuşmazlık çözümlerini, Türk hukuk sistemi açısından nasıl uygulamamız gerektiği sorusunu gündeme getirmiş bulunmaktadır.

Geleceğe yönelik olarak bakıldığında, medeni yargılama hukuku açısından da bundan sonra hem geleneksel hem de bunun dışında online uyuşmazlık çözüm yöntemlerinin birlikte değerlendirilmesinin önem taşıyacağı görülmektedir. Dünyada muhtelif ülkelerin hukuk sistemleri incelendiğinde, online uyuşmazlık çözümlerinin yaygın hale gelmeye başladığı ve COVID-19 salgınının da bu süreci süratle hızlandırdığı gözlenmektedir. Online uyuşmazlık çözümleri kapsamında yer alan online tahkim yöntemi de dünyanın çeşitli ülkelerinde uygulama alanı bulan bir uyuşmazlık çözme biçimidir. Çalışmamızın konusu, online tahkimin ne olduğunu tanıtarak, dünyada online tahkimi kullanan çeşitli kurum ve kuruluşların uygulama yöntemlerinden çeşitli örnekler vererek, ülkemizde de yeni gelişmekte olan kurumsal tahkimi, online tahkim ile birlikte yeni gelişmeler karşısında, yargılamanın temel ilkeleri ile bağlantılı olarak değerlendirmeyi hedeflemektedir.

\section{Genel Olarak Online Tahkim}

Dünyada online tahkime yönelik ilk önemli girişim, 1996 yılında "Sanal Sulh Hakimi”" (Virtual Magistrate) veya kısaltılmış adıyla (VMAG) projesi ile gerçekleşmiştir. Bu proje, büyük ölçüde akademik bir çalışma idi ve Villanova Bilgi Merkezi ev sahipliği ile Ulusal Otomatik Bilgi Araştırmaları Merkezi tarafından finanse edilmekteydi. Proje geliştiricilerinin amacı, üçüncü tarafların sistemlerinde ortaya çıkan haksız iletişim iddialarını ileri sürdükleri zaman, sistem operatörlerine uyuşmazlıkları çözebilecekleri bir forum (veya mahkeme) ortamı sağlamaktı. ${ }^{3}$ Nitekim VMAG projesinden bugüne çeşitli ticari online uyuşmazlık çözüm sistemleri online arabuluculuktan online tahkime kadar çeşitli hizmetler sunarak yayılmış bulunmaktadır. $^{4}$

Doktrinde bazı yazarlar tarafından özellikle online ortamda gerçekleşen tahkim için, kesin bir işlevsel tanımın olmadığı ifade edilmektedir. ${ }^{5}$ Bununla birlikte tahkim, geleneksel anlamdaki tanımı ile taraflar arasındaki hukuki bir uyuşmazlığın devlet mahkemelerinde görülmesine ilişkin yolun kapatılması şartı ile yargılama yetkisine sahip özel üçüncü kişiler tarafından çözüme kavuşturulmasıdır. ${ }^{6}$ Buna karşılık online

\footnotetext{
Doktrinde "Virtual Magistrate" hakkında geniş bilgi için Bkz Karen Stewart /Joseph Matthews, "Online Arbitration of Cross-Border, Business to Consumer Disputes", (2002), 56, U Miami Law Review, 1123 vd.

Stewart/Matthews, (n 3) 1124.

Paul Schwarzenbaker, “Online Arbitration: A European and US Perspective”, (2018), 10, Bocconi Legal Papers, 405.

6 Alangoya, (n 2) 4; Ziya Akıncı, "Elektronik Tahkim” (DEÜ Yayını 2002), Uluslararası İnternet Hukuku Sempozyumu, 429; Deren-Yıldırım, (n 2) 37; Alangoya/Yıldırım/Deren-Yıldırım, (n 2) 595.
} 
tahkim (online arbitration) ise, online uyuşmazlık çözümleri kapsamı içinde yer alan ve geleneksel (offline) tahkimin tüm özelliklerine sahip bulunan, internet üzerinden elektronik ortamda gerçekleşen bir tahkim yöntemi olarak belirtilmektedir. ${ }^{7}$ Doktrinde bazı yazarlar ise, online tahkimin, offline tahkimin bir versiyonu olduğunu ${ }^{8}$ ve hatta online tahkimi, "elektronik tahkim" anlamına gelen "e- arbitration” şeklinde de ifade etmektedirler. ${ }^{9}$

Genel olarak online tahkim, münhasıran internet ve dijital teknolojinin kullanımı yoluyla yerine getirilmekte ${ }^{10}$ ve bilgi teknolojisinden tahkim alanında da faydalanılmasını ifade etmektedir. ${ }^{11}$ Bilgi teknolojisinin kullanım derecesine bağlı olarak da iki kategoriye ayrılmaktadır. Bunlardan birincisi, bilgi değişimi ve iletişim aracı olarak bilgi teknolojisini kullanmak için sınırlanmış "teknoloji destekli online tahkim”" (technology-assisted online arbitration), diğeri ise, bilgi teknolojisinin tam teşekküllü uygulamasının online tahkimde kullanıldı̆̆ “teknoloji tabanlı online tahkim" (technology-based online arbitration) şeklinde ifade edilmektedir. ${ }^{12}$ Teknoloji destekli online tahkim, online tahkimin temel sorunlarına temas etmez iken, teknoloji tabanlı online tahkim, geçerli bir tahkimin gerektirdiği minimum adilliği ve verimliliği arasındaki dengenin önemi konusunda ciddi bir konuya dikkat çekmektedir. ${ }^{13}$

\section{Dünyanın Çeşitli Ülkelerinde Online Tahkim Uygulamaları}

Dünya genelinde online tahkim kurallarının, uygulandığ 1 tahkim kurumuna göre farklılıklar gösterdiği görülmektedir. ${ }^{14}$ Bununla birlikte online tahkim yargılaması, Uluslararası Ticaret Odası ("ICC"), Amerikan Tahkim Birliği (“AAA”), Dünya Fikri Mülkiyet Organizasyonu ("WIPO”), "Shenzen Tahkim Komisyonu” ("SZAC”) Çin Uluslararası İktisadi ve Ticari Tahkim Komisyonu ("CIETAC”), Guangzhou Tahkim Komisyonu ("GZAC"), " Rus Tahkim Birliği ("RAA”) gibi birçok tahkim kurumları tarafından etkin bir şekilde uygulama alanı bulmaktadır. Dünyada kurumsal olarak tahkim ve arabuluculuk konusunda hizmet veren kurumlar sadece burada

\footnotetext{
Armağan Ebru Bozkurt Yüksel, “Elektronik Ticarette Alternatif Uyuşmazlık Çözümü”, (2008), 123, Mevzuat Dergisi, (www.mevzuatdergisi.com); Melis Ercan, Uyuşmazlıkların Online Çözüm Yöntemleri, 2012, (yayınlanmamış ylt), 100.

8 Chinthaka Liyanage, "Online Arbitration Compares to Offline Arbitration and the Reception of Online Consumer Arbitration: An Overview of the Literature", (2010), 22, Sri Lanka Journal of International Law, 175; Julio César Betancourt/ Elina Zlatanska, "Online Dispute Resolution (ODR): What Is It, and Is It the Way Forward?", (2013), 79, International Journal of Arbitration, Mediation and Dispute Management, 262; Dafna Lavi, "Three is not a Crowd: Online Mediation-Arbitration in Business to Consumer Internet Disputes”, (2016), 37, U.Pa.J.Int'l L, 885.

9 Liyanage, (n 8) 175; Betancourt/Zlatanska, (n 8) 262;

10 Amy J. Schmitz, "Drive-Thru" Arbitration in the Digital Age: Empowering Consumers Through Binding ODR" , (2010), 62, BAYLOR LAW. REVIEW, 182; Philip Johnson, "Enforcing Online Arbitration Agreements for Cross-Border Consumer Small Claims in China and the United States”, (2013), 36, HASTINGS INT'L \& COMP. L. REV, 583; Lavi, (n 8) 885.

11 Jie Zheng, "The Recent Development of Online Arbitration Rules in China", (2017), 26 Information \& Communications Technology Law, 135.

12 Zheng, (n 11) 135.

13 ibid 135 .

14 Çakır/Dalar, (n 1) 228.
} 
yazdıklarımız ile sınırlı değildir. Bununla birlikte uzun zamandan beri ağırlıklı olarak online tahkim üzerine çalışan ve gelişmeler gösteren bu kurumların kural ve esaslarına bizde çalışmamız bünyesinde yer vermeye çalışacağız.

\section{A. Amerikan Tahkim Birliği (American Arbitration Association)}

"Amerikan Tahkim Birliği”" (American Arbitration Association), kısaltılmış adıyla (“AAA”), 1926 y1lında kurulmuştur. ${ }^{15}$ Bu kuruluş, günümüzde online arabuluculuk dışında, WebFile hizmeti yoluyla hızlı ve uygun online davaların açıldığı ve kısmen online çözümlenen davaların yer aldığı bağlayıcı bir tahkim sunmaktadır. Buna ek olarak yine bu sistem aracıllığıla uyuşmazlığın tarafları ödeme yapabilmekte, online dava yönetimini yerine getirebilmekte; elektronik bir şekilde belgeleri transfer ederek aktarabilmekte, tarafların anlaşmalarına uygun olarak hakemleri veya arabulucuları seçebilmekte, davayı özelleştirmek için mesaj panosunu kullanabilmekte ve davanın durumunu kontrol edebilecek şekilde sunulan bütün hizmetlerden yararlanmaktadır. ${ }^{16}$

Yine WebFile sisteminin sunduğu hizmete göre, kullanıcı kayıt formunu doldurduğunda bir şifre (password) seçmektedir. Bu şifre sayesinde, online taleplerini dosyalamak için kullanıcı sisteme erişebilmektedir. Aynı şekilde "online alan adı uyuşmazlıkları" (online domain name disputes) ile ilgili açılmış davalar Amerikan Tahkim Birliği tarafindan yürütülebilmektedir. ${ }^{17} \mathrm{Bu}$ konu ile ilgili olarak örneğin, doktrinde WebFile sistemi yoluyla 2006 yılında 3,099 dava açıldığı ve bunlardan 1,100 den fazlasının arabuluculuk ile ilgili olduğu ifade edilmektedir. Bu verilen rakamlarla doğru orantılı olarak da 569 davada taraflar, arabulucu ve hakemlerini online seçmiş bulunmaktadır. Hukukun birçok farklı alanı ile ilgili olan bu davalar arasında iş hukuku, ticaret hukuku, inşaat hukuku ve uluslararası hukuk ile bağlantılı uyuşmazlıklar da yer almaktadır. ${ }^{18}$

Amerikan Tahkim Birliği, online tahkim için genel kurallara ilave olarak, "Online Tahkimler için Tamamlayıcı Kurallar” (Supplementary Rules for Online Arbitrations) isimli bir kurallar listesi düzenlemiştir. Buna göre, online tahkime ilişkin bütün prosedürler Amerikan Tahkim Birliği’nin online tahkim yargılaması için öngördüğü usuli esas ve kurallara bağlı olarak yürütülmektedir. Bu kuralların amacı, tahkim yargılamasının münhasıran online olarak yapılmasına ve çözümlenmesine izin vermektir. ${ }^{19} \mathrm{Bu}$ ek kurallar, aynı zamanda online tahkimin nasıl gerçekleştiğini

\footnotetext{
Schwarzenbaker, (n 5) 405.

16 Ihab Amro, Online Arbitration in Theory and in Practice, A Comprative Study of Cross-Border Commercial Transactions in Common Law and Civil Countries, (Cambridge Scholars Publishing 2019), 92.Doktrinde Amerikan Tahkim Birliği'nin online tahkim uygulamaları hakkında ayrıntılı bilgi için ayrıca Bkz Schwarzenbaker, (n 5) 407 vd.; Schmitz, (n 10) 187.

17 Amro, (n 16) 92-93 (dipnotu 230 da adı geçen yazar).

18 Amro, (n 16) 93.

19 M. H. M. Schellekens, "Online Arbitration and E-Commerce", (2002), 9, Electronic Communication Law Review, 114; Çakır/Dalar, (n 1) 229-230.
} 
gözünde canlandırmaya da yardımcı olmaktadır. Bu usuli kurallara göre, online tahkim ile ilgili "Vakıa Sitesi" (Case Site) olarak isimlendirilen temel bir kavram bulunmaktadır. Buna göre, her bir uyuşmazlık için yeni bir "vakıa sitesi” tesis edilmektedir. Uyuşmazlığın taraflarına ait tüm dava dosyaları ve talepler burada muhafaza edilmektedir. $\mathrm{Bu}$ vakıa sitesinde yer alan bilgi ve belgelere sadece Amerikan Tahkim Birliği, uyuşmazlığın tarafları ve hakem (hakemler) kendileri adlarına oluşturulacak üyelik bilgileri ile erişmeye yetkili kılınmaktadır. ${ }^{20}$

Uyuşmazlığın taraflarından birinin, karşı taraf ile olan ihtilâfını online tahkim yoluyla çözümlemek istediği hallerde, bu talebini Amerikan Tahkim Birliği’nin İdari Site'sine elektronik ortamda göndermesi gerekmektedir. Eğer bu talep, tahkim prosedürünün yürütülmesi için gerekli bütün bilgileri içeriyorsa ve davacı taraf da ücretini ödemiş bulunuyorsa, Amerikan Tahkim Birliği tarafından bir vakı sitesi oluşturulmakta ve bunu takiben, her iki tarafta vakıa sitesinin adresi hususunda bilgilendirilmektedir. Amerikan Tahkim Birliği, davalı tarafı bilgilendirmek için, davalıya ait olan ve davacı tarafından sağlanan e-mail adresini kullanmaktadır. ${ }^{21}$

Bu süreçte davalı tarafa e- mail yoluyla ulaşılamaması halinde, Amerikan Tahkim Birliği tarafından söz konusu davanın online ortamda yürütülemeyeceğine karar verebileceği ve bu durumun davacı tarafa bildirilmesi gerektiği belirtilmektedir. Genel olarak, uyuşmazlığın taraflarından birinin online tahkime katılma kapasitesinin yetersizliği veya Amerikan Tahkim Birliği’nin takdir yetkisine bağl olarak tahkimin, online olarak yürütülmemesi gerektiğinin tespiti halinde, tahkimin online olarak yapılmayacağına karar verilebileceği kabul edilmektedir. ${ }^{22}$ Dolayısıyla burada tahkimin online ortamda yapılamayacağına geleneksel yöntemle yapılmasına dair karar verme yetkisi, tahkim sağlayıcısı konumunda bulunan Amerikan Tahkim Birliği'ne ait bulunmaktadır.

Buna karşılık, bildirimin e-mail yoluyla başarılı olarak ulaştığı hallerde ise, tahkim süreci vakıa sitesinin tesis edildiği tarihte başlamaktadır. Bu tarih, taraflara gönderilen doğrulayıcı nitelikteki e-mailde belirtilmiş bulunmaktadır. Davalı taraf, vakı sitesine bir yanıt göndermektedir. Bu yanıt, talebe yapılan fili cevap ve onu destekleyen delil ve argümanlar, tahkime itiraz, vakıa sitesi ile iletişim için kullanacağ1 e-mail adresi ve muhtemelen karşı iddia (karşı dava) talebini ihtiva etmektedir. Bu bağlamda bir karşı dava açıldığı takdirde, davacı tarafın buna, otuz gün içinde davaya cevap vermesi gerekmektedir. Yargılamayı yürüten hakem de kararını kural olarak duruşma olmaksızın, ibraz edilen belge ve delillere dayalı olarak vermektedir. Online ortamda duruşma, sadece taraflardan biri veya her ikisi de talep ettikleri takdirde gerçekleşmektedir. Duruşma, tarafların hakem huzurundaki

\footnotetext{
Schellekens, (n 19) 114; ibid 229-230.

21 ibid 114; ibid 230.

22 ibid 114.
} 
bir toplantısı olup, bizzat veya telefon ile ya da telekonferans yoluyla veya başka yollarla yürütülebilmektedir. Duruşmada tanık ifadesi alınabileceği, tanıkların çapraz sorgulamasının yapılabileceği; tahkim yargılamasını yürüten hakem tarafından onaylandığı takdirde, ek belgelerin delil olarak alınabileceği öngörülmektedir. ${ }^{23}$ Tahkim yargılaması sonunda hakem tarafından verilen karar vakıa sitesine ibraz edilerek, taraflara da e-mail yoluyla bildirilmektedir. ${ }^{24}$

\section{B. Dünya Fikri Mülkiyet Organizasyonu (World Intellectual Property Organization)}

“Dünya Fikri Mülkiyet Organizasyonu” (World Intellectual Property Organization) kısaltılmış adıyla ("WIPO”), 1967 yılından beri faaliyetine devam eden bir kuruluştur. Fikri mülkiyet alanında meydana gelen uyuşmazlıkların çözümü safhasında kuruluş bünyesi içinde bir tahkim merkezinin kurulması 1990’lı y1llarda gerçekleşmiştir. Dünya Fikri Mülkiyet Organizasyonu'na bağlı tahkim ve arabuluculuk merkezi 1994 yılında faaliyete başlamış ve halen de çalışmalarına devam etmektedir. ${ }^{25}$ Dünya Fikri Mülkiyet Organizasyonu, aralarında tahkim, arabuluculuk ve alan adı uyuşmazlıklarının da bulunduğu birçok ihtilâfın çözümünde alternatif uyuşmazlık çözümleri hizmeti sunmaktadır. ${ }^{26}$

Özellikle alan adı ile ilgili uyuşmazlıkların çoğunluğu bu kuruluş tarafından çözümlenmektedir. ${ }^{27}$ Ayrıca online tahkim uygulamasının dünyadaki başarılı uygulama örneklerinden bir tanesi de Dünya Fikri Mülkiyet Organizasyonu tarafından yerine getirilen kısaltılmış adı ile "ICANN" olarak bilinen "İnternet Tahsisli Sayılar ve İsimler Kurumu" (Internet Corporation for Assigned Names and Numbers) tahkim usulüdür. ${ }^{28}$ ICANN sadece elektronik ortamdaki alan adlarına ilişkin uyuşmazlıklar açısından Dünya Fikri Mülkiyet Organizasyonu bünyesinde mevcut bulunan bir online tahkim türüdür. Bu tahkim türüne ilişkin olarak kısa adıyla ("UDNDPR") olarak bilinen "Alan Adı Uyuşmazlıklarının Çözümünde Yeknesak Kurallar” (Uniform Domain Name Dispute Resolution Policy) isimli hüküm ve

27 Ercan, (n 7) 105. Bu konuda geniş bilgi için Bkz Murat Atalı, "İnternet Ortamında Tahkim ve Usul Hukuku Sorunları", (2007), 60, e - Akademi, Hukuk, Ekonomi ve Siyasal Bilimler Aylık Dergisi, parg.10.

28 Stewart/Matthews, 1124; Elizabeth G. Thornburg, "Going Private: Technology, Due Process, and Internet Dispute Resolution", (2000), 34, University of California, Davis, 153, 160-165; David E. Sorkin, "Judicial Review of ICANN Domain Name Dispute Decisions", (2001), 35, 18 Santa Clara Computer \& High Tech. L.J., 35; Thomas Schultz, "Online Arbitration: Binding or Non-Binding?", (2002,) ADR Online Monthly, 2; Konstantinos Komaitis, "Pandora's box is finally opened: The Uniform Domain Name Dispute Resolution Process and Arbitration", (2005), 19, International Review of Law, Computers \& Technology, 100; Andrea M. Braeutigam, "Fusses That Fit Online: Online Mediation in Non-Commercial Contexts", (2006), 5, Appalachian Journal Law, 278; Bartosz Ziemblicki, "Going Online-Is The World Ready to Replace Litigation with Online Dispute Resolution Mechanism”,(2015), 5, Wroclaw Review of Law, Administration \& Economics, 46; Çakır/Dalar, (n 1) 231; Amro, (n 16) 92.
} 
esaslar uygulama alanı bulmaktadır. ${ }^{29}$ UDNDPR, ticari markaları kapsayan alan adı uyuşmazlıklarını hızlı bir şekilde çözmek için kolaylaştırılmış bir "siber tahkim" (cyber arbitration) prosedürü yaratmıştır. ${ }^{30} \mathrm{Bu}$ sistem, nispeten alan adları hakkında, alan adının bir başkası tarafından alınması veya ileride satılmak amacıyla kötü niyetli kişilerin benzer alan adlarını tescil etmesinden (cybersquatting) kaynaklanan problemleri çözmek için ${ }^{31}$, "basit” uyuşmazlıklar bakımından tasarlanmıştır. Buna karşılık alan adı ile ilgili karmaşık davaların çözümünün geleneksel mahkemelere bırakıldığ 1 ifade edilmektedir. ${ }^{32}$

Burada uyuşmazlığın çözümü, ICANN tarafindan onaylanan uyuşmazlık çözümü sağlayıcılarından biri tarafından gerçekleştirilmektedir. Başvurular çeşitli şekillerde örnek vermek gerekirse; telekomünikasyon veya faks iletimi, posta veya kurye hizmeti veya elektronik olarak yerine getirilmektedir. Merkez, elektronik iletişimi kolaylaştırmak için internet tabanlı bir vakıa dosyalama ve yönetim sistemi oluşturmuştur. Kural olarak, hakem heyeti kendi takdir yetkisine dayanarak, dava hakkında duruşma yapmanın gerekli olduğuna karar vermedikçe, yüz yüze duruşma yapılmamaktadır. ${ }^{33}$ Heyetin bu doğrultudaki kararı, bütün taraflara, ICANN ve kayıt memuru olarak adlandirılan (registrar) tarafa, alan adını kayıt eden davalının kuruluşuna bildirilmektedir. Heyetin bu kararına karşı, davalı taraf, şikâyet edene karşı yetkili mahkemede dava açıp da bu durumu kayıt memuruna bildirmediği takdirde, kayıt memuru tarafindan alan adı kaydı, devir veya iptal edilmektedir. Heyetin bu kararı da kural olarak internette yayınlanmaktadır. ${ }^{34}$

\section{Shenzen Tahkim Komisyonu (Shenzhen Arbitration Commission)}

Çin Halk Cumhuriyeti'nde zirvedeki beş tahkim merkezinden biri olarak Shenzen Tahkim Komisyonu (Shenzhen Arbitration Commission) kısaltılmış adı ile ("SZAC") yer almaktadır. Shenzen Tahkim Komisyonu, online uyuşmazlık çözümleri, girişimlerinin bir bölümü olarak online tahkim, elektronik delil koruma hizmetleri platformu şeklinde ve kısa adıyla ArbiCloud olan "Bulut Tahkim Platformu" (Cloud Arbitration Platform) sistemini başlatmıştır. ${ }^{35} \mathrm{Bu}$ sistem dört önemli alanda online uyuşmazlık çözümleri için hizmet vermektedir. Bunlardan birincisi, Smart online tahkim sistemidir. $\mathrm{Bu}$ sistem, yerli ve yabancı tarafların hukuki ve ticari uyuşmazlıkları için tam zamanında hizmet sağlamak amacıyla hazırlanmıştır.

\footnotetext{
29 Braeutigam, (n 28) 278, Sorkin, (n 28) 35 vd.; Schultz, (n 28) 2; Komaitis, (n 28) 103; Schellekens, ( n 19) 116; Ercan (n 7), 104; Ziemblicki, (n 28) 46; Cakır/Dalar, (n 1) 232; Amy J. Schmitz, "Building on OArb Attributes in Pursuit of Justice" (2018), 9, ( http://ssrn.com/abstract= 3118229); Amro, (n 16) 92.

30 Komaitis, (n 28) 103.

31 Ziemblicki, (n 28) 46.

32 Schellekens, (n 19) 116.

33 Braeutigam, (n 28) 278; Schellekens, (n 19) 116.

34 ibid 116-117.

35 Amro (n 16), 93.
} 
Dünyanın farklı ülkelerinde bulunan taraflar, tahkim başvurularını, iletişimlerini, hakemlerin seçimini ve video-konferans yoluyla mahkeme oturumuna bağlanmayı online ortamda yapabilecektir. İkincisi, Elektronik Delil Koruma ve Güçlendirme Hizmetleri'dir. Bu sistem, yargısal duruşma problemlerinde üç anahtar faktörden oluşan tarafsızlık, geçerlilik ve meşruiyetten oluşan elektronik delil kanıtını çözümlemeyi hedeflemektedir. Nitekim bu online hizmet, e- mail, QQrecord, Wechat, SMS ve diğer elektronik işlem verilerinin, tahrifat ve kaybolmasından kaçınmak için, zaman damgası (time stamps) ve dijital belgeleme ile mühürlenmiş olarak arşivlenmiş şekilde saklanması ve muhafaza edilmesine izin vermektedir. Kullanıcılar ve arşiv arasındaki bağlantı ("SZAC") copyright yazılım ("Z-agent security middleware") şeklindedir. ${ }^{36}$ Üçüncüsü, Online Noterlik Hizmetleri, bir taraftan hukuki sonucu noter tarafından onaylanmış hizmetleri sağlamaktadır. Diğer taraftan da elektronik delilin güvenilirlik ve kanuna uygunluğunu tasdik ederek bu hizmeti yerine getirmektedir. Son olarak ArbiCloud, kullanıcıların online platformlarını online uyuşmazlık çözümlerine gönderebilmek için APIs sistemi sağlamakta ve sistem ile ArbiCloud arasında veri değişimine izin vermektedir. ${ }^{37}$

\section{Guangzhou Tahkim Komisyonu (Guangzhou Arbitration Commission)}

Çin Halk Cumhuriyeti'nin önde gelen kurumsal uyuşmazlık çözüm merkezlerinin başında gelen ve kısa adıyla (CIETAC) olarak bilinen "Çin Uluslararası İktisadi ve Ticari Tahkim Komisyonu" (China International Economic and Trade Arbitration Commission) ${ }^{38}, 2009$ y1lından bu yana "alan adı uyuşmazlıkları" (domain name disputes) ve "elektronik ticaret uyuşmazlıkları" (e-commerce disputes) için tahkim kurallarını ilan etmesine rağmen, CIETAC Online Tahkim Kuralları (CIETAC Online Arbitration Rules), elektronik delillerin değişimi ve doğruluğunun ispat edilmesi konusunda belirli koşullar altında offline veya geleneksel tahkim kurallarından çok fazla ayrılmamaktadır. ${ }^{39}$

Bununla birlikte yakın zamanlarda Çin Halk Cumhuriyeti'nde kısaltılmış adıyla ("GZAC") olarak bilinen Guangzhou Tahkim Komisyonu (Guangzhou Arbitration Commission) tarafından online tahkimi, teknoloji tabanlı online tahkime değiştiren yenilikçi bir girişim yapılmıştır. Guangzhou Tahkim Komisyonu, 23.06.2015 tarihinde, 01.10.2015 tarihinden itibaren geçerli olmak üzere online tahkim kurallarını yayınlamak suretiyle, Çin Halk Cumhuriyeti'nde online tahkim kurallarını

\footnotetext{
36 Amro, (n 16) 93, dn 232 .

37 ibid 93,232

38 Bu konuda geniş bilgi için Bkz Seda Özmumcu, Uzak Doğu'da Arabuluculuk Anlaylşı ile Türk Hukuk Sisteminde Arabuluculuk Kurumuna Genel Bir Bakış, (3. Baskı, Oniki Levha 2013), 176 vd.

39 Zheng, (n 11) 135-136. Bu konuda ayrıca Bkz Cemre Çise Kadığlu, "Brick and Clicks: Online Dispute Resolution Mechanism and Implamentation of Online Arbitration in Turkey for Cross-Border Business to Consumer E-Commerce Disputes", (2019), 1, ASBÜ Bilişism Hukuku Dergisi, 121.
} 
benimseyen ikinci komisyon olmuştur. ${ }^{40}$ Buna karşılık CIETAC Online Tahkim Kuralları ise, 01.01.2015 tarihinden itibaren geçerlidir. ${ }^{41}$

Doktrinde Guangzhou Tahkim Komisyonu’nun online tahkime ilişkin kurallarının, online tahkimde esneklik ve verimlilik ihtiyaçları yönünden yenilikçi kurallar belirlemek bakımından CIETAC Online Tahkim Kuralları'ndan daha radikal olduğu ifade edilmektedir. ${ }^{42}$ Guangzhou Tahkim Komisyonu, online tahkim davalarını yürütmek için online tahkim platformu kurmuş bulunmaktadır. Tahkim kuralları, genel online tahkim kuralları ve belirli uyuşmazlık türleri için örneğin, küçük meblağlı online alışveriş uyuşmazlıkları, online kredi uyuşmazlıkları ve kredi kartı uyuşmazlıkları olmak üzere üç ayrı tahkim esasından oluşmaktadır. ${ }^{43}$

Aslında GZAC Online Tahkim Kuralları, kendilerini uyuşmazlık türleri açısından sınırlandırmış olmamakla birlikte, genel olarak online kredi, alışveriş ve kredi kartı uyuşmazlıkları gibi küçük meblağlı hak talepleri veya internet uyuşmazlıkları için daha uygun bulunmaktadır. Bunun nedeni, sadece online tahkim prosedürlerinin, offline veya geleneksel tahkim prosedürlerinden daha basit ve etkili olması değil, aynı zamanda internet uyuşmazlıklarında elektronik delillerin daha kolay elde edilmesidir. $^{44}$

Burada taraflar arasındaki tahkim anlaşması, henüz uyuşmazlık ortaya çıkmadan önce veya uyuşmazlık ortaya çıktıktan sonra basılı veya elektronik ortamda hazırlanarak imza edilebilmektedir. Bunun dışında ayrıca uyuşmazlığın taraflarından biri, bir tahkim başvurusunda bulunmuş olup da, karşı taraf da herhangi bir itirazda bulunmayıp, online tahkim yargılamasına katılmış ise, dolaylı olarak veya zımnen bir tahkim anlaşmasının yapıldığ 1 varsayılmaktadır. ${ }^{45}$

Uyuşmazlığın tarafları, belge ve delillerini online tahkim platformu aracılığıyla ve istedikleri zaman bu belgelere başvurmak suretiyle ibraz edebilmektedir. Tahkim belgeleri, tahkim anlaşmasında taraflarca sağlanan e-mail, cep telefonu veya diğer iletişim araçları yoluyla iletilmektedir. Online alışveriş uyuşmazlıkları durumunda, web sitelerinin kaydı sırasında, taraflarca kullanılan e-mail adresi tahkim sırasında iletişim için kullanılmaktadır. Bu özellikle web sitelerinin hüküm ve şartları ile akdedilen tahkim hükümleri için tasarlanmıştır. Tahkim belgelerinin varsayılan teslim süresi, online tahkim platformunun, tahkim belgelerini taraflara başarıyla teslim edildiğini gösterdiği zaman olarak öngörülmektedir. Bu arada GZAC, alıcının cep telefonuna hatırlatma amacıyla kısa bir mesaj göndermektedir. GZAC sistemi

\footnotetext{
$40 \quad$ ibid 136.

41 İbid 136, dn 5; Kadıŏlu, (n 39) 121.

42 ibid 136.

43 ibid 136.

44 ibid 136.

45 ibid 137.
} 
ile alıcının sistemi arasındaki teslimat süresiyle ilgili tutarsızlık olması durumunda, alıcının sisteminin teslimat süresi, yeterli delille ispatlanması koşuluyla geçerli kabul edilmektedir. ${ }^{46}$

Uyuşmazlığın taraflarından biri, herhangi bir iletişim aracı belirtmemişse veya diğer tarafça veya GZAC tarafından herhangi bir iletişim aracı bulunamamışsa, GZAC tarafindan o taraf için belirlenen tahkim e-mail adresi olarak online tahkim platformu aracılığıyla bir e-mail adresi oluşturulmaktadır. Böylelikle GZAC, taraflara belirlenen e-mail adresi ve şifreyi posta yoluyla bildirdikten sonra, belirtilen e-mail adresine teslim edilen tüm belgeler taraflara teslim edilmiş sayılmaktadır. ${ }^{47}$

$\mathrm{Bu}$ sistemde online tahkim, online duruşmalar ile desteklenen yazılı işlemler yoluyla gerçekleştirilmektedir. Hakem heyeti gerekli gördüğü zaman, bu iletişim sırasında taraflara eşit muameleyi sağlarken; aynı zamanda davayı yargılamak için de online video konferans, online iletişim veya telefon konferansı gibi çeşitli elektronik iletişim yollarını kullanabilmektedir. ${ }^{48}$ Tahkim işlemleri sırasında, tahkim kurulu online tahkim platformu aracılı̆̆ıla, taraflara bir soru listesi verebilmekte ve buna göre de tarafların beş gün içinde ilgili sorulara cevap vermeleri istenmektedir. Aksi takdirde, tarafların açıklama haklarından feragat ettikleri varsayılmaktadır. ${ }^{49}$

Bununla birlikte online tahkim bütünüyle offline veya geleneksel tahkim usulünden izole edilip, soyutlanmış değildir. Online tahkim işlemleri, uyuşmazlık taraflarının kimliklerini ispatlamak için destekleyici belgeler ibraz etmemeleri ve bu arada kimliklerinin araştırma yoluyla doğrulanmasının mümkün olmadığı hallerde veya tarafların offline tahkime dönüşüm yapmayı kabul ettiklerinde ya da tahkim mahkemesinin uyuşmazlığın karmaşıklı̆ı̆ını göz önünde bulundurarak offline veya geleneksel tahkimi kullanmaya karar vermesi durumunda, online tahkim offline tahkim yargılamasına dönüşebilecektir. ${ }^{50}$

Uluslararası tahkim alanında, "tahkim yeri” kavramı, kanuni ikametgâh veya yargı yerinin bulunduğu yeri ifade etmektedir. Bu kavram, genel olarak tahkim kararına ne ölçüde itiraz edileceğini etkileyen tahkim kararının milliyetini belirlemektedir. Online tahkim sırasında ise, online tahkimin fiziksel bir yeri olmadığından ve çoğu yargı yetkisinde tahkimin ulusal bir yarg1 sistemine bağlanmadan hareket etmesine izin verilmediğinden ek kurallar gerekmektedir. Bu bağlamda genelde GZAC Online Tahkim Kuralları'nda, eğer taraflar tahkim yerini kararlaştırmamışlarsa, Guangzhou belediyesi, Guangzhou Tahkim Komisyonu'nun tahkim yeri olarak öngörülmektedir. Guangzhou Tahkim Komisyonu, ayrıca ihtilâfların diğer faktörlerini de dikkate

\footnotetext{
ibid 137.

47 ibid 137.

48 ibid 138.

49 ibid 138.

s0 ibid 138.
} 
alarak, diğer yerleri de tahkim yeri olarak belirleyebilecektir. Böylelikle online tahkim kararı, tahkim yerinde verilmiş sayılacaktır. ${ }^{51}$

Burada tahkim kararları, hakemlerin ve Guangzhou Tahkim Komisyonu'nun elektronik imzalarına eklenmiş tahkim heyeti tarafından verilmektedir. Tahkim kararları tarafların belirlenmiş e-mail adreslerine gönderilmektedir ve fakat kâğıt formundaki kararlar, tarafların talebi üzerine Guangzhou Tahkim Komisyonu tarafindan da verilebilecektir. ${ }^{52}$

Online tahkim kuralları etkili bir online tahkim kararının, mahkemeler tarafindan tanınmasını ve uygulanmasını sağlamak için etkililik ve adalet arasında bir denge sağlamalıdır. Çünkü taraf özerkliği ilkesi, tahkimin temel dayanağıdır. Tahkim, uyuşmazlık taraflarının tahkim anlaşmasında kabul ettikleri kurallar ve prosedürler ile bağlantılı olarak yürütülmektedir. ${ }^{53}$

Taraflar arasında yazılı bir tahkim anlaşmasının bulunmadığı hallerde, tahkim komisyonu davayı kabul etmeyecektir. Bu bağlamda Çin Halk Cumhuriyeti Tahkim Kanunu'nun 4.maddesinin yargısal yorumuna göre de, yazılı bir sözleşme, mektup veya elektronik veri metni (telgraf, faks, elektronik veri değişimi ve e-mail) dâhil olmak üzere yazılı olarak tahkim anlaşması formlarına geniş bir yorum sağlamaktadır. Çin Halk Cumhuriyeti Tahkim Kanunu'nun 4. maddesinin 2. cümlesi, bu konuda açık bir düzenlemeyi içermektedir. Buna göre, tahkim komisyonunun, taraflar arasında yazılı bir tahkim anlaşmasının bulunmadığı hallerde ise, taraflardan birinin yapmış olduğu başvuruyu kabul etmeyeceği öngörülmüştür. Diğer taraftan GZAC Online Tahkim Kuralları'na göre, taraflardan birinin, tahkim mahkemesinin ilk duruşmasından önce tahkim anlaşmasının geçerliliğine itiraz etmediği hallerde, bundan sonra tahkim sözleşmesi veya tahkim kararına karşı, herhangi bir anlaşma olmadığını iddia ederek, itiraz etmesine izin verilmemektedir. ${ }^{54}$

GZAC Online Tahkim Kuralları, taraflara elektronik veya kağıt formu dâhil olmak üzere, uyuşmazlıklardan önce veya sonra yazılı olarak veya online tahkim prosedürlerine katılım gibi eylemlerle, tahkim anlaşması yapmak için çeşitli seçenekler sunmaktadır. Ayrıca, GZAC tarafların karşılıklı mutabakat ile online tahkimi, offline tahkime çevirmesine izin vermektedir. Bununla birlikte uyuşmazlığın taraflarının, tahkim yargılaması sırasında duruşma yapılıp yapılmamasını seçemeyecekleri ve takdir yetkisini tahkim mahkemesine bırakmaları gereği kabul edilmektedir. ${ }^{55}$

\footnotetext{
ibid 138 .

ibid 139.

3 ibid 139.

55 ibid 139.
}

54 ibid 139. 
Tahkim yargılamasının temel prensiplerinden biri olarak bir diğer prensip, eşit muamele ilkesidir. Bu ilke, taraflardan hiç birine, diğerine göre üstünlük tanınmaması ve eşit muamele edilmesi anlamına gelmektedir. $\mathrm{Bu}$ bağlamda UNCITRAL Uluslararası Ticari Tahkim Model Kanunu'nun 18.maddesi gereğince de taraflara eşit muamele edilmesi öngörülmektedir. Online tahkim yargılamasında uyuşmazlığın tarafları, tahkim mahkemesi ve diğer tarafla bağlantı kurmak için video konferans, e-mail yazışmaları gibi bilgi teknolojilerini kullanmak suretiyle, tahkim belgelerini ibraz etmek ve teslim almak için online platformu da kullanabilmektedir. Bu nedenle, taraflar eşit muamele ihtiyacını karşılamak için benzer teknolojik olanaklar ile donatılmalıdır. $\mathrm{Bu}$ teknolojik olanaklar, benzer bağlantı hızıyla elektronik belgelerin yüklenmesi ve indirilmesi ile internete erişim gibi temel bilgisayar bilgilerini içermektedir. ${ }^{56}$

Tahkim yargılamasının temel prensiplerinden bir başkası ise, tarafların bildirim alma hakkıdır. Bu hak, uyuşmazlık taraflarının önemli bir usuli hakkıdır. Eğer taraflardan birine tahkim yargılaması veya hakem atanması konusunda bilgi verilmemişse, bu durum tahkim kararının iptali için bir dayanak oluşturmaktadır. GZAC Online Tahkim Kuralları, uyuşmazlık taraflarının uygun şekilde bilgilendirilmesini sağlamak için farklı bildirim yöntemlerinin (örneğin e-mail ve cep telefonu gibi) birleşimini kabul etmektedir. E-mail dağıtım sisteminde bir problem olduğunda veya taraflardan biri, önemli belgeleri alamadığını ileriye sürdüğünde, sorunlar ortaya çıkmaktadır. $\mathrm{Bu}$ sebeple, elektronik belgelerin tam olarak ne zaman teslim edildiğini ispatlamak bir delil konusudur. Posta ile ilgili olarak fiziki ortama benzer şekilde posta ile göndermede olduğu gibi, bir e-mailin ne zaman başarıla gönderildiği hususu belirsiz kalmaktadır. Çünkü e-mail teslimat süreci hedefe ulaşmadan sonsuz sayıda sunucudan geçebilmektedir. Bu sebeple alıcının, e-maili bilgisayarından indirmek suretiyle, İnternet Servis Sağlayıcısı (Internet Service Provider) aracılığıyla alması gerekmektedir. Genellikle e-mail alıcıya ulaşmadığı takdirde, gönderen teslimat hatası bildirimi almaktadır. Buna karşıllk gönderen, e-mailin ne zaman teslim edildiğini ve ne zaman okunduğunu onaylamak için bir teslim raporu ve bir okundu bilgisi isteyebilmektedir. İleri teknoloji yeniliği sayesinde, elektronik belgelerin teslimini ispatlayan yeni teknolojiler mevcut bulunmaktadır. Bunlardan biri, taraflar arasında veri mesajlarını (data messages) elektronik yollarla aktaran ve veri mesajların gönderme ve alma kanıtı da dahil olmak üzere iletilen verilerin işlenmesine ilişkin delil sağlayan elektronik kayıt hizmetidir ve bu hizmet, iletilen veri mesajlarını zarar veya herhangi izinsiz değişimlere, hırsızlık veya kaybetme riskine karşı korumaktadır. Bu konuda bir başka seçenek ise, online tahkim platformunda tarafların bu elektronik dağıtım sistemi aracılığıyla belge alabileceği ve gönderebileceği bir elektronik dağıtım sistemi oluşturmaktır. ${ }^{57}$

\footnotetext{
6 ibid, 140.

57 ibid, 141
} 
Tahkim yargılamasının gerekli süreç şartları arasında yer alan ana ilkelerden bir diğeri de hukuki dinlenilme hakkıdır. Bu ilke, her bir tarafın davasını oluşturmak için yeterli zamana sahip olmasını sağlamaktadır. Bu prensip, yargı yetkisine itiraz etme, bir hakkı ileri sürme, hakemleri seçme ve delilleri inceleme hakkı gibi geniş bir içeriğe sahip bulunmaktadır. Çin Halk Cumhuriyeti'nde hukuki dinlenilme hakkının reddedilmesi, gerek yurt içi gerek yurt dışı tahkimde hakem kararlarının iptali için yasal bir dayanak oluşturmaktadır. Bu durum aynı zamanda New York Sözleşmesi’nin V (1) (b) maddesi gereğince uluslararası tahkim kararının iptali gerekçelerinden de bir tanesidir. Online tahkimde, uyuşmazlıkların çoğu basit olayları (örnek olarak, satış sözleşmeleri, kredi sözleşmeleri ve ödeme sözleşmeleri gibi) içerdiğinden ve küçük talepli anlaşmazlıklar olduğundan, bu davalara genellikle tarafların yazılı beyanlarına dayanarak tahkim kurulu tarafindan karar verilmektedir. ${ }^{58}$

\section{Rus Tahkim Birliği (Russian Arbitration Association)}

Online uyuşmazlık çözümleri kapsamında online tahkim ile yakından ilgili olan k1sa adıyla ("RAA") olarak tanınan "Rus Tahkim Birliği" (Russian Arbitration Association) de bu alanda önde gelen kuruluşlar arasında yer almaktadır. Rus Tahkim Birliği, taraflar arasında sözleşmeden veya sözleşme dışı işlemlerden kaynaklanan ticari uyuşmazlıkların çözümünü kolaylaştırmak için online tahkim sistemini kurmuş bulunmaktadır. Nitekim Rus Tahkim Birliği'nin Online Tahkim Kuralları 01.10.2015 tarihinden itibaren yürürlüktedir. ${ }^{59}$

Rusya'da Rus Tahkim Birliği’nin online tahkime ilişkin başlıca kuralları, öncelikle genel hükümler ve sistemin tanıtılması ile başlamaktadır. Bunu takiben, online tahkim katılımcı veya katılımcıları, tahkim süresi, tahkim yargılamasının yeri ve tahkim yargılamasının dili, hakem atanması, hakeme itiraz ve hakem değişikliği yapılması, tahkim yargılamasının başlaması, dava dilekçesi verilmesi, online tahkimin başlaması, cevap dilekçesi sunulması ve bunların dışında uygulanacak hukuk kuralları ve delilleri düzenlemektedir. Bundan başka sözü edilen kurallar, taraflardan birinin hazır bulunmaması ve delil sunmaması, yargılamanın duruşmalı veya duruşma yapılmasızın yürütülmesi ve dostane çözüm anlaşmasına varılması gibi konuları da tanzim etmektedir. ${ }^{60}$

ibid, 141-142.

59 Amro, (n 16) 94; Kadıŏlu, (n 39) 121.

60 ibid 94. 


\section{IV. Ülkemizde Kurumsal Tahkim ile İlgili Yasal Düzenlemeler}

\section{A. 6570 sayılı İstanbul Tahkim Merkezi Kanunu}

Türk hukuk sisteminde tahkimin kurumsal olarak yerini alması 6570 sayıl1 İstanbul Tahkim Merkezi Kanunu ile gerçekleşmiştir. Kanun, 01.01.2015 tarihinde yürürlüğe girmiş bulunmaktadır. Buna bağlı olarak İstanbul Tahkim ve Arabuluculuk Merkezi veya İstanbul Tahkim Merkezi ve kısaltılmış adıyla ("ISTAC"), 6570 sayılı İstanbul Tahkim Merkezi Kanunu ile kurulmuştur. ${ }^{61}$

İstanbul Tahkim Merkezi Kanunu'nun 1.maddesine göre, "Bu Kanunun amacl, yabancllık unsuru taşlyanlar da dâhil olmak üzere uyuşmazlıkların tahkim veya alternatif uyuşmazllk çözüm yöntemleriyle çözülmesini sağlamak üzere İstanbul Tahkim Merkezinin kurulması ile Merkezin teşkilat ve faaliyetlerine ilişkin usul ve esaslart düzenlemektir." denilmektedir. Bu hükümden de görüleceği üzere, İstanbul Tahkim Merkezi gerek yabancılık unsuru içeren ve gerekse yabancılık unsuru içermeyen uyuşmazlıkların tahkim veya alternatif uyuşmazlık çözüm yöntemleri ile çözüme kavuşturulmasında görev üstlenmektedir. Bu bağlamda Kanun'un 4.maddesi, İstanbul Tahkim Merkezi'nin görevlerini, “a) Tahkim ve alternatif uyuşmazlık çözüm yöntemlerine ilişkin kuralları belirlemek ve hizmetlerin yürütülmesini sağlamak. b) Tahkim ve alternatif uyuşmazlık çözüm yöntemleriyle ilgili tanıtım ve yayın yapmak, bu konudaki bilimsel çalışmaları teşvik etmek, desteklemek, gerçekleştirmek, yurt içi ve yurt dişındaki ilgili kişi ve kurumlarla iş birliği yapmak" şeklinde düzenlemiş bulunmaktadır.

\section{B. İstanbul Tahkim Merkezi ve Online Tahkim Usulü ve Esasları}

Dünyayı etkileyen COVID-19 salgını ile birlikte ülkemizde de İstanbul Tahkim Merkezi tarafindan Nisan 2020 itibariyle "ISTAC Çevrimiçi Duruşma Usul ve Esasları" yayınlanmıştır. Toplamda on maddeden oluşan bu usul ve esasların 1.maddesi gereğince, Çevrimiçi Duruşma Usul ve Esaslarının amacının, ISTAC kurallarına göre yürütülen tahkim davalarında katılımcıların fiziksel olarak bir araya gelmeden telekonferans veya video konferans yöntemi ile yapacakları duruşmalarda uygulanacak usul ve esasları belirlemek olduğu ve burada kullanılan "duruşma" teriminden çevrimiçi duruşma kavramının anlaşılacağı ifade edilmektedir. Aynı hükmün 2. fikrasına göre, hakem veya hakem kurulunun, taraflardan birinin talebi üzerine veya kendiliğinden, hukuki dinlenilme hakkına uyulmak kaydıyla, burada önerilen usul ve esaslardan farklı kurallar belirleyebileceği kabul edilmektedir.

\footnotetext{
T1 Türkiye'de ilk olarak 6570 say1lı İstanbul Tahkim Merkezi Kanunu ile kurulan İstanbul Tahkim ve Arabuluculuk Merkezi veya İstanbul Tahkim Merkezi hakkında ayrıntılı bilgi için Bkz Mehmet Rıfat Bacanlı, "Bir Alternatif Uyuşmazlık Çözüm Yolu Olarak İstanbul Tahkim ve Arabuluculuk Merkezi (ISTAC) Tahkim Yargılamasında Delillerin İbrazı ve Değerlendirilmesi”, (2016), 8, Uyuşmazlık Mahkemesi Dergisi, 75 vd.
} 
Online tahkim prosedürü, fiziki ortamda olmayıp sanal ortamda yerine getirileceği için bunun, taraflardan birinin talebi üzerine veya hakem veya hakem kurulunun uygun görmesi halinde, duruşma veya toplantıların video konferans veya telekonferans yöntemi ile yapılabileceği öngörülmektedir (md 2).

Online ortamda yapılacak duruşma için gerçekleştirilecek olan hazırlıklar konusunda, hakem veya hakem kurulunun, tarafların da görüşünü alarak duruşmanın hangi yazılım kullanılarak yapılacağı, duruşmanın gizlilik ve güvenliği için alınması gereken tedbirlerin, katılımcıların duruşmaya katılması için gereken telefon numarası, link, kullanıcı adı veya şifre gibi sair hususları duruşmadan önce belirleyip duruşmanın teknik altyapısını oluşturarak taraflarla paylaşacağı ifade edilmektedir (md 3/1). Duruşmaya katılacak kişilerin, katılım için gerekli olan teknik donanım ve yazılımı, bulundukları mekânın dinlenilmeye elverişli ve güvenli bir mekân olmasını kendileri sağlayacağı belirtilmektedir (md 3/2).

Online tahkim yargılamasında uyuşmazlığın taraflarının duruşmaya katılacak olan kişileri duruşma öncesine hakem veya hakem kuruluna bildirmeleri gerekmektedir (md 4/1). Tarafların duruşma esnasında, duruşmaya katılması bildirilen ve izin verilenler dışında kalan üçüncü bir kişiyi duruşma ortama dâhil etmelerine müsaade edilmemektedir (md 4/2).

İstanbul Tahkim Merkezi’nin Çevrimiçi Duruşma Usul ve Esasları çerçevesinde, online ortamda yapılacak tahkim yargılamasında, duruşma sırasında ibraz edilmek istenen belgelerin ancak hakem veya hakem kurulunun iznine bağlı olarak elektronik ortamda iletilebilmesi kabul edilmektedir (md 6).

Tahkim yargılamasında sadece geleneksel tahkimde değil, aynı zamanda online ortamda yapılan tahkim açısından da büyük önem taşıyan ve usule ilişkin esaslar arasında yer alan konulardan biri de hukukî dinlenilme hakkının yerine getirilmesidir. ${ }^{62}$ Hakem veya hakem mahkemesi de online tahkim ortamında her iki tarafa eşit şekilde hukuki dinlenilme hakkı tanıyarak kararını vermelidir. Anayasa'nın 36. maddesi ile teminat altına alınan iddia ve savunma hakk1 ile adil yargilanma hakkı, hukuki dinlenilme hakkını da kapsamaktadır. ${ }^{63}$ Hukuki dinlenilme hakk1, Anayasa'nın 36.maddesinde ve Avrupa İnsan Hakları Sözleşmesi’nin 6.maddesinde adil yargılanma hakkının da en önemli unsurlarından biridir. ${ }^{64}$

Hukukî dinlenilme hakkı, yargılama ile birlikte bundan hukuki durumu etkilenecek kimselerin, yargılama konusunda bilgi edinmelerini, açıklamada bulunmalarını ve

\footnotetext{
Doktrinde hukuki dinlenilme hakkı ile ilgili geniş bilgi için Bkz Hakan Pekcanıtez, "Hukuki Dinlenilme Hakkı", (2000), (Prof. Dr. Seyfullah Edis'e Armağan), 753 vd.

${ }^{63}$ Pekcanitez Usûl Medenî Usûl Hukuku, C.I, (15. Bası, Oniki Levha 2017), 862.

${ }_{64}$ Pekcanıtez Usûl, (n 63) 863.Bu konuda ayrıca Bkz Muhammet Özekes, Medeni Usul Hukukunda Hukuki Dinlenilme Hakk1, (Yetkin 2003), 30
} 
yargılamaya etki edebilmelerini ve yargılama görevini yerine getiren makamların bunları dikkate alarak ve gerekçeli olarak karar vermelerini sağlayan ve tarafları sürpriz kararlardan koruyan temel bir yargilama ilkesidir. ${ }^{65} \mathrm{Bu}$ hak, sadece belli bir yargılama veya yargılamanın belli bir aşaması geçerli olan bir ilke olmayıp; tüm yargılamalarda ve yargılamanın her safhasında uyulması gerekli bir ilkedir. ${ }^{66}$

$\mathrm{Bu}$ bağlamda online tahkim yargılaması sırasında da bu ilkeye önemle riayet edilmesi gerekmektedir. İstanbul Tahkim Merkezi'nin Çevrimiçi Duruşma Usul ve Esasları, online ortamda gerçekleştirilecek olan tahkim yargılamalarında bu konuyu düzenlemiştir. Buna göre, hakem veya hakem kurulu, tarafların ve diğer ilgililerin duruşmaya katılma imkânına sahip olduğundan ve hukuki dinlenilme hakkının ihlal edilmediğinden emin olmak için gereken özeni göstermekle yükümlüdür. Bununla birlikte hakem veya hakem kurulunun duruşma sırasında hukuki dinlenilme hakkının ihlâl edildiğine kanaat getirmesi halinde, gerekçesini belirterek duruşmayı istediği zaman sonlandırabilme yetkisi bulunmaktadır ( $\mathrm{md} \mathrm{7)}$.

Online ortamda yerine getirilecek tahkim yargılamasında, tanık ve bilirkişilerin dinlenmesi de büyük önem taşımaktadır. İstanbul Tahkim Merkezi'nin Çevrimiçi Duruşma Usul ve Esasları kapsamında bu konu, online ortamda tanık veya bilirkişi dinlenilmesine karar verilmesi halinde, tanık veya bilirkişi video konferans yoluyla ve görüntülü olarak duruşmaya katılacaktır. Online duruşmaya katılan tanık veya bilirkişinin, yüzü açıkça görülebilir bir şekilde kameranın karşısında hazır bulunması gerekmektedir. Buna ilave olarak tanığın veya bilirkişinin yanında herhangi bir belgenin bulunup bulunamayacağına karar verme yetkisi, hakem veya hakem kuruluna ait olup, duruşma sırasında belirli bir belgenin tanı̆ga gösterilmesine izin verebilmektedir. Hakem veya hakem kurulunun uygun bulması durumunda, tanığa gösterilecek belge, duruşma esnasında elektronik olarak paylaşılarak soru sorulabilecektir (md 8).

Geleneksel veya offline tahkimde gizlilik ilkesi, uyuşmazlık taraflarının devlet mahkemelerine gitmeyip, ihtilafı kamuoyuna duyurmadan çözümlemeleri için kabul ettikleri esasların başında gelen en temel ilkelerinden biridir. Bu ilke, online ortamda yürütülen tahkim yargılamasında da büyük bir öneme sahiptir. Bu doğrultuda "İstanbul Tahkim Merkezi Çevrimiçi Duruşma Usul ve Esasları" gereğince, hakem veya hakem kurulunun, taraflara bilgi vererek, duruşmanın sesli veya görüntülü olarak kaydedilmesine karar verebileceği ve kayıtların duruşmanın bitimini takiben taraflarla paylaşılacağı ve aynı zamanda masrafları taraflara ait olmak üzere, ses kayıtlarının yazılı hale getirilmesine hakem veya hakem kurulu tarafindan karar verilebileceği öngörülmüştür. Bununla birlikte hakem veya hakem kurulunun onayı

\footnotetext{
65 Özekes, (n 64)31, Atalı, (n 27) parg. 39.

66 Pekcanitez Usûl, (n 63), 864.
} 
olmaksızın duruşmanın herhangi bir aşamasında görüntü ve ses kaydı alınmasının yasak olduğu kabul edilmiştir (md 10).

\section{Online Tahkimin Olumlu ve Olumsuz Yönleri}

Online tahkim yargılaması, uyuşmazlık taraflarının tamamen fiziki ortamda yüz yüze gelmediği ve tanıkların şahitliklerini yine sanal ortamda yerine getirerek ifade verdiği internet üzerinden yürütülmektedir. Bazı yazarlar tarafından online uyuşmazlık çözümlerinin, yüz yüze yapılan alternatif uyuşmazlık çözümlerinin birçok avantajlarını karşıladı̆̆ı, geleneksel tahkime göre, daha az formal, artırılmış hızı ve daha düşük maliyet ile uyuşmazlıkların çözülmesine yardımcı olduğu ifade edilmektedir. Aynı şekilde online tahkimin de geleneksel tahkimden hem daha hızlı hem daha ucuz olduğu belirtilmektedir. ${ }^{67}$

Online tahkim yargılamasının, uyuşmazlıkların çözülmesi noktasında belliaçılardan yararları olduğu kabul edilse de, bazı konularda olumsuz yönleri de bulunmaktadır. Bu doğrultuda, COVID-19 salgınının yeni bir gerçekliğe hızla ve benzeri görülmemiş bir şekilde uyum sağlamayı gerekli kılması, uyuşmazlıkların online tahkim yoluyla çözümü bakımından düşündürücü bir durum yaratabilecektir. Bu bağlamda ortaya konulan sorunlardan biri, hakemlerin sanal ortamda online yapılan duruşmalara aşina olmadıkları hususudur. ${ }^{68}$ Hakemlerin "bulut tabanlı" (cloud-based) belge paylaşımı ve video konferans yöntemini deneyimlemiş olabilecekleri ve fakat farklı yerlerde herkesle yapılan duruşma kavramının, bazı hakemler tarafından bilinmediği belirtilmektedir. Buna ek olarak, hakemlerin uzaktan katılım deneyimleri çoğu zaman teknolojik başarısızlıklarla gölgelenebilmekte ve bu da onları teknolojiye bağlılıklarını artırma konusunda temkinli hale getirmektedir. ${ }^{69}$

Yine bu konuda başlıca sorulardan bir diğeri de, herkes ayrı yerlerde olduğundan, ortaya çıkabilecek teknik sorunların nasıl çözümleneceği meselesidir. Özellikle uluslararası online tahkim yargılamalarında, tahkimde görevli avukatlık ekipleri ve tahkimde görev alanlar, katılımcıların uyanık oldukları saatlere göre, kısa telekonferanslar için zaman bulma zorluğuna tanıdık olacaklardır. ${ }^{70}$

Online tahkim yargılaması ile ilgili dezavantaj yaratacağı düşünülen bir başka konu ise, özellikle çapraz sorgulama sırasında tanık ifadesini değerlendirirken, şahsen gözlem yapma kaybının, hakem mahkemesinin kanıtların gücünü ve güvenilirliğini değerlendirme yeteneğini olumsuz yönde etkileyeceği endişesinin duyulmasıdır.

\footnotetext{
C. Steven Bradford, "Online Arbitration as a Remedy for Crowdfunding Fraud", (2018), 45, Florida State University Law Review, 1192.

68 Janet Walker, "Virtual Hearings: An Arbitrator's Perspective Int-Arb Arbitrators" 2020, 1 (https://int-arbitrators.com/wpcontent/uploads). Bu konuda benzer şekilde ayrıca Bkz Hale Kutlay, "Online Arbitration in Turkish Law", (2011), 2, GSI Articletter, 25.

69 Walker, (n 68) 1.
}

70 ibid 1 . 
Özellikle bilgisayar ekranında tanık delilini değerlendirirken, onun görünüm ve duygusunu, beden dilini, yüz ifadelerini, sesindeki ton değişikliklerini yakalamanın zor olabileceği ifade edilmektedir. ${ }^{71}$ Bunun dışında uzaktan katılım, tanığın hakem heyetinin görüş alanından gizlenmiş bir yazıdan okuması veya kamerasının çalıştırılamaması gibi endişeleri gündeme getirmektedir. Böyle bir durumun tanığın sanal delilinin işe yararlılığı ve doğruluğu hakkında şüphe uyandırabileceğine işaret edilmektedir. ${ }^{72}$

Fikrimizce büyük bir hızla gelişen teknoloji bu noktada karşılaşılabilecek engelleri de minimum düzeye indirmek için gerekli atılımları yerine getirecek güce sahip bulunmaktadır. Nitekim online tahkimin bu olası olumsuz yönlerinin bazı teknolojik açılardan olumlu yöne çevrilebileceğine değinilmektedir. Bu konuda örneğin, Zoom ve Bluejeans gibi uygulamaları kullanan görsel-işitsel teknolojinin bazı önemli özelliklerinin kurulu teknolojilerin işlevselliğini hızlı bir şekilde geliştirdiği belirtilmektedir. Birçok katılımcı ile şahsen duruşmanın en önemli özelliğinin, hızlı bir şekilde ard arda birçok katılımcıyı gözlemlemek için odayı tarama firsatı verdiğine dikkat çekilmektedir. ${ }^{73}$

Bununla birlikte tüm teknolojik ihtiyaçların bu kadar etkili bir şekilde karşılanmasının mümkün olmayacağına işaret edilmektedir. İnternet bağlantısının zayıf olduğu yerlerde bulunan katılımcılar için sihirli bir çözüm olmadığına ve onlar için ses ve görüntü kalitesi ile güvenilirliğin, daha iyi hizmet verilen alanlara göre mutlaka geride kalacağına temas edilmektedir. Bu noktada ticari ve tüketici faaliyetleri arasında seyahat ve uzaktan katılım zorlukları meydana geleceğinden, bu hususa bir kamu hizmeti olarak daha fazla öncelik verilmesi gerektiğine değinilmektedir. ${ }^{74}$

\section{Değerlendirme ve Sonuç}

Dünya uygulamalarında alternatif uyuşmazlık çözümleri kapsamında yer alan tahkim ve arabuluculuk gibi uyuşmazlık çözme yöntemlerinin, bazı ülkelerde kurumsal olarak yerine getirildiği görülmektedir. Bu bağlamda ülkemiz de yakın tarihlerde 6570 sayılı İstanbul Tahkim Merkezi Kanunu ile kurulan İstanbul Tahkim Merkezi aracılığıyla uyuşmazlıkların tahkim ve arabuluculuk gibi alternatif yöntemlerle çözümü konusunda kurumsal bir yapıya sahip olmuştur.

Dünyada 1970'li yılların sonunda ortaya çıkmaya başlayan alternatif uyuşmazlık çözüm (alternative dispute resolution) (ADR) yöntemleri; 1990'll y1llarda internet ile birlikte 1990'lı yılların sonu ve 2000'li yılların başından itibaren alternatif uyuşmazlık

\footnotetext{
ibid 1.

72 İbid 1

73 ibid 2
}

74 ibid 2. 
çözümlerinden, online uyuşmazlık çözümlerine (online dispute resolution) (ODR) doğru dijital bir sürece ilerlemeye başlamıştır. Batı da online uyuşmazlık çözümleri ve bu kapsamda online tahkim de dahil olmak üzere, alternatif uyuşmazlık çözümlerinin ve devlet mahkemelerinin önüne geçmeye çalışmaktadır.

Online uyuşmazlık çözümlerinin ülkemize bu kadar büyük bir hızla yansıması ise, COVID-19 salgını ile gündeme gelmiştir. Türk hukuk sistemi bünyesinde, İstanbul Tahkim Merkezi çevrimiçi duruşmalara ait usul ve esaslarını düzenleyerek yakın tarihlerde yayınlanmıştır. Batı dünyasındaki hızlı gelişmeleri online uyuşmazlık çözümleri noktasında belirli bir ölçüde takip ederken, COVID-19 gerçeği, gerçek dünyadan sanal dünyaya geçiş noktasında ülkemizde de etkilerini ve yansımalarını hızlı bir teknolojik süreç ile göstermeye başlamıştır.

Bu yeni dünya düzeninde, Türk hukuk sistemi de kendini teknolojik gelişmelere uyarlamaya ve online tahkim platformları oluşturmaya çalışmaktadır. Bu noktada online tahkim yargılamalarında ortaya çıabilecek teknik sorunların büyük bir hızla çözümleneceği düşüncesini taşımaktayız. Zira COVID-19 nedeniyle bütün dünyada, bilim insanlarının teknolojiden kaynaklı sorunlara çözüm bulma çaba ve gayreti içinde oldukları görülmektedir. Bu sebeple internete erişim ile ilgili teknolojik sorunların belli bir süre içinde aşılacağı görüşündeyiz.

Fakat burada önemle üzerinde durmak istediğimiz konu, "internete erişim"den ziyade "adalete erişim" ile ilgilidir. Özellikle online ortamda yerine getirilecek olan tahkim yargılamalarında, hakem veya hakem heyeti tarafindan bağlayıcı nitelikte bir hüküm verilmesi sebebiyle, adil yargılanma ve hukuki dinlenilme hakk1 gibi yargılamanın temel ilkelerine daha büyük bir özen gösterilmesi gereklidir. Zira bir uyuşmazlığın çözümü için verimlilik, hızlılık, az maliyet bu sürecin avantajlı yönleri olsa bile, adaletin yerine getirilmesi de çok önemlidir. Bu bağlamda online tahkim yargılamalarında adilliğin ve adaletin sağlanması, toplum düzeninin ve hukuki barışın korunması açısından son derece önem taşımaktadır.

\footnotetext{
Hakem Değerlendirmesi: Dış bağımsız.

Çıkar Çatışması: Yazar çıkar çatışması bildirmemiştir.

Finansal Destek: Yazar bu çalışma için finansal destek almadığını beyan etmiştir.

Peer-review: Externally peer-reviewed.

Conflict of Interest: The author has no conflict of interest to declare.

Grant Support: The author declared that this study has received no financial support.
} 


\section{Bibliyografya/Bibliography}

Akıncı Z, “Elektronik Tahkim”, (DEÜ Yayını 2002),Uluslararası İnternet Hukuku Sempozyumu, s.429-435.

Alangoya Y, Medeni Usul Hukukumuzda Tahkimin Niteliği ve Denetlenmesi, (1973)

Alangoya H.Y /Yildırım M K/

Deren-Yıldırım N, Medeni Usul Hukuku Esaslarl, (7.Bask1, Beta 2009).

Amro I, Online Arbitration in Theory and in Practice, A Comprative Study of Cross-Border Commercial Transactions in Common Law and Civil Countries, (Cambridge Scholars Publishing 2019).

Atalı M, “İnternet Ortamında Tahkim ve Usul Hukuku Sorunları”, (2007), 60, e - Akademi, Hukuk, Ekonomi ve Siyasal Bilimler Aylık Dergisi, 1-21.

Bacanlı M R, "Bir Alternatif Uyuşmazlık Çözüm Yolu Olarak İstanbul Tahkim ve Arabuluculuk Merkezi (ISTAC) Tahkim Yargılamasında Delillerin İbrazı ve Değerlendirilmesi”, Uyuşmazlık Mahkemesi Dergisi, (2016), 8, 75-113.

Betancourt J C/ Zlatanska E, "Online Dispute Resolution (ODR): What Is It, and Is It the Way Forward?", (2013), 79, International Journal of Arbitration, Mediation and Dispute Management,256-264.

Bradford C. S, "Online Arbitration as a Remedy for Crowdfunding Fraud", (2018), 45, Florida State University Law Review, 1169-1124.

Braeutigam M A, "Fusses That Fit Online: Online Mediation in Non-Commercial Contexts", (2006), 5, Appalachian Journal Law, 1169-1124.

Bozkurt Yüksel A E, "Elektronik Ticarette Alternatif Uyuşmazlık Çözümü”, (2008), 123, Mevzuat Dergisi, (www.mevzuatdergisi. com).

Çakır G/ Dalar E, “Arbitration via Internet Environment Online Arbitration", (2018), 19, GSI Articletter, 223-236.

Deren-Yıldırım N, “Tahkimin Olumlu ve Olumsuz Yönleri”, (2002), 4, ABD, 37-44.

Ercan M, Uyuşmazlıkların Online Çözüm Yöntemleri, Ankara, 2012, (yayınlanmamış ylt).

Johnson P, "Enforcing Online Arbitration Agreements for Cross-Border Consumer Small Claims in China and the United States”, (2013), (36), HASTINGS INT'L \& COMP. L. REV, 577-602.

Kadıŏglu C Ç, "Brick and Clicks: Online Dispute Resolution Mechanism and Implamentation of Online Arbitration in Turkey for Cross-Border Business to Consumer E-Commerce Disputes", (2019), 1, ASBÜ Bilişim Hukuku Dergisi, 113-146.

Komaitis K, "Pandora's box is finally opened: The Uniform Domain Name Dispute Resolution Process and Arbitration", (2005), 19, International Review of Law, Computers \& Technology, 99-116.

Kutlay H, "Online Arbitration in Turkish Law”, (2011) 2, GSI Articletter, 24-26.

Lavi D, "Three is not a Crowd: Online Mediation-Arbitration in Business to Consumer Internet Disputes”, (2016), 37 U.Pa.J.Int'1 L., 871-941.

Liyanage C, "Online Arbitration Compares to Offline Arbitration and the Reception of Online Consumer Arbitration: An Overview of the Literature", (2010), 22, Sri Lanka Journal of International Law, 173-194.

Özekes M, Medeni Usul Hukukunda Hukuki Dinlenilme Hakks, (Yetkin 2003).

Özmumcu S, “Uzak Doğu’da Arabuluculuk Anlayışı ile Türk Hukuk Sisteminde Arabuluculuk Kurumuna Genel Bir Bakış”, (3. Bas1, Oniki Levha 2013). 
Özsunay E, “Tahkim Yargılamasında Mahremiyet”, (2004), 2, İBD, 541-560.

Pekcanıtez, H, “Hukuki Dinlenilme Hakkı”, 2000, (Prof. Dr. Seyfullah Edis’e Armağan), 753-791.

Pekcanıtez H, Medenî Usûl Hukuku, C.I, (15. Bası, Oniki Levha 2017).

Schellekens M. H. M., "Online Arbitration and E-Commerce”, (2002), 9, Electronic Communication Law Review, 113-126.

Schmitz J A, "Drive-Thru" Arbitration in the Digital Age: Empowering Consumers Through Binding ODR", (2010), 62, BAYLOR LAW REVIEW, 178-244.

Schmitz J A, "Building on OArb Attributes in Pursuit of Justice", (2018), 9 ( http://ssrn.com/ abstract $=3118229$ ).

Schultz T, “Online Arbitration: Binding or Non-Binding?”, (2002), 2, ADR Online Monthly, 1-22.

Schwarzenbaker P, "Online Arbitration: A European and US Perspective", (2018), 10, Bocconi Legal Papers, 387-423.

Sorkin D E, "Judicial Review of ICANN Domain Name Dispute Decisions", (2001), 35, 18 Santa Clara Computer \& High Tech. L.J, 35-55.

Stewart K / Matthews J, "Online Arbitration of Cross-Border, Business to Consumer Disputes", (2002), 56, U Miami Law Review, 1111-1146.

Thornburg G E, "Going Private: Technology, Due Process, and Internet Dispute Resolution", (2000), 34, University of California, Davis, 151-220.

Walker J, "Virtual Hearings: An Arbitrator's Perspective Int-Arb Arbitrators" 2020, 1; (https://intarbitrators.com/wp-content/uploads).

Zheng J, "The Recent Development of Online Arbitration Rules in China”, (2017), 26 Information \& Communications Technology Law, 135-145.

Ziemblicki B, "Going Online-Is The World Ready to Replace Litigation with Online Dispute Resolution Mechanism", Wroclaw Review of Law, Administration \& Economics, (2015), 5, 40-51. 